\title{
Effects of an extreme drought on the endangered pearl mussel Margaritifera margaritifera: a before/after assessment
}

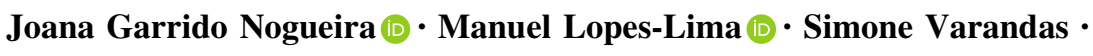 \\ Amílcar Teixeira $\cdot$ Ronaldo Sousa
}

Received: 18 July 2019/Revised: 28 September 2019/Accepted: 11 October 2019

(C) Springer Nature Switzerland AG 2019

\begin{abstract}
Droughts can change the distribution and alter the behaviour, phenology and physiology of many species, leading in extreme cases to high mortalities or even extirpation. In this study, a before/after comparison was performed in two Portuguese river basins (Rabaçal and Tuela) to assess the possible effects of an extreme drought on the abundance and size structure of two pearl mussel Margaritifera margaritifera populations, a Critically Endangered species in Europe. The hydrological year of 2017 was extremely dry in Portugal and this situation was responsible for a major reduction of the river flow and rapid decrease in the water levels during summer. One year after the drought, a significant reduction in abundance was observed (i.e. $27.6 \%$ for the Rabaçal and $38.7 \%$ for the Tuela basin populations). However, no differences were detected in the
\end{abstract}

Guest editors: Manuel P. M. Lopes-Lima, Nicoletta Riccardi, Maria Urbanska \& Ronaldo G. Sousa / Biology and Conservation of Freshwater Molluscs

J. G. Nogueira $(\bowtie) \cdot$ R. Sousa

CBMA - Centre of Molecular and Environmental

Biology, Department of Biology, University of Minho,

Campus Gualtar, 4710-057 Braga, Portugal

e-mail: joanafgnogueira93@gmail.com

J. G. Nogueira · M. Lopes-Lima

CIBIO/InBIO - Research Center in Biodiversity and

Genetic Resources, University of Porto, Campus Agrário de Vairão, Vairão, Portugal size structure of the two pearl mussel populations. Droughts are predicted to increase in number and intensity and it is crucial to monitor $M$. margaritifera populations, given the low resistance (and possibly low resilience) of this species to these extreme conditions. Management measures that could help the conservation of pearl mussels are discussed.

Keywords Climate change $\cdot$ Conservation $\cdot$ Extreme climatic events $\cdot$ Mortality $\cdot$ Resilience $\cdot$ Resistance

\section{Introduction}

Extreme climatic events (e.g. floods, droughts and heat waves) are likely to increase in frequency, magnitude and intensity in the coming decades (Sterl et al., 2008; Rammig \& Mahecha, 2015). These extreme events may have negative effects on biodiversity due to direct

\footnotetext{
S. Varandas

CITAB-UTAD - Centre for Research and Technology of Agro-Environment and Biological Sciences, Forestry Department, University of Trás-os-Montes and Alto Douro, Vila Real, Portugal

A. Teixeira

Centro de Investigação de Montanha (CIMO), Instituto Politécnico de Bragança, Campus de Santa Apolónia, 5300-253 Bragança, Portugal
} 
mortality (Garrabou et al., 2009), changes to the phenology and physiology of organisms (Siegmund et al., 2016) including the reduction of the reproductive ability (Sales et al., 2018), and alterations on species distributions (Wuethrich, 2000). Extreme climatic events may also change population and community dynamics and ecosystem functions with long-lasting effects (Walther et al., 2002; Bellard et al., 2012) or even be responsible for regime shifts (Harris et al., 2018; Maxwell et al., 2019).

Droughts, in particular, can be described as meteorological events related to precipitation deficits of significant magnitude over a prolonged time and/or area (Lake, 2011). The occurrence of droughts and its legacy in freshwater ecosystems have been particularly well documented (Hastie et al., 2003; Golladay et al., 2004; Bond et al., 2008; Haag \& Warren, 2008). Examples include the alterations in freshwater mussel assemblages (lower densities and species richness) due to the synergistic effect of drought and a decrease in reservoir releases in Kiamichi River (USA) responsible for the increased mortality of thermally sensitive species (Galbraith et al., 2010).

According to their periodicity, droughts can be divided in two main types: seasonal, which are predictable and periodic; and supra-seasonal that are characterized by an unpredictable decline in precipitation (Humphries \& Baldwin, 2003). Organisms may respond differently to both types of droughts. In one hand, and since seasonal droughts are predictable, organisms are able to develop mechanisms to increase survivorship such as life-history scheduling, the use of refuges or migration to more suitable habitats (Winemiller \& Jepsen, 1998; Chester \& Robson, 2011). On the other hand, supra-seasonal droughts are erratic in time and duration, making it more difficult for organisms to develop coping mechanisms of resistance and adaptation (Lake, 2003). Our knowledge of the consequences of seasonal droughts on biodiversity is greater, which is understandable given the low predictability of supra-seasonal droughts (Lake, 2003).

Freshwater mussels (Bivalvia, Unionida), being benthic organisms with low mobility, may be highly prone to the negative effects of droughts and consequent reduction in water availability (Golladay et al., 2004). In fact, a direct effect of drought is the reduction of water quantity leading to the exposure of river banks, which in turn reduces the available habitat for some species (Lake, 2011), including freshwater mussels (Santos et al., 2015). These organisms may dominate the biomass of some freshwater ecosystems and are considered indicator species since they respond to environmental disturbance (Lopes-Lima et al., 2014, 2018). In addition, freshwater mussels are highly threatened being considered one of the most imperilled groups of organisms in aquatic ecosystems and over the last years the number of studies dealing with the conservation of these species increased substantially, mainly on North America and Europe (Lopes-Lima et al., 2014, 2017).

The pearl mussel Margaritifera margaritifera (Linnaeus, 1758) is one of the freshwater mussel species with highest conservation importance, and the number of ecological studies and applied conservation programmes increased substantially in the last two decades (Geist, 2010; Lopes-Lima et al., 2017; Sousa et al., 2019). This species is one of the most threatened bivalves in Europe being classified as Endangered (Critically Endangered in Europe) by the IUCN, and protected by the European Union under annexes II and $\mathrm{V}$ of the European Commission Habitats Directive [92/43/EEC]. Margaritifera margaritifera occurs in oligotrophic waters, and requires specific fish hosts (Salmo salar and Salmo trutta) for their larvae to metamorphose (Varandas et al., 2013). Given that $M$. margaritifera prefers to live near the banks at lower depths in Portuguese rivers, and have almost no locomotor capacity after settlement, this species is highly vulnerable to desiccation caused by water shortage during droughts (Varandas et al., 2013; Sousa et al., 2015, 2018). In addition to desiccation, pearl mussels are more prone to predation during droughts given the lower water depth (Sousa et al., 2018) and to inefficient management of water released from dams (Sousa et al., 2015).

Theoretically, freshwater species may respond to changes in climate by altering geographic ranges and dispersing to northern latitudes or higher altitudes. However, species like M. margaritifera have little to no mobility and depend on other species to disperse (i.e. fish hosts). Furthermore, the Iberian populations of M. margaritifera occur at the southern limit of the species distribution (Sousa et al., 2013, 2015) and recent changes in temperature, precipitation or increase of extreme events have been responsible for high mortalities (Sousa et al., 2012; Santos et al., 2015). Despite the potential high impacts generated by 
climate change on $M$. margaritifera, very few studies attempt to quantify the before/after effects of extreme events such as droughts.

Given the poor conservation status of M. margaritifera in Europe, the main aim of this study is to assess the effects of the 2017 drought in pearl mussel populations colonizing two Iberian basins (Rabaçal and Tuela). Building on an earlier study (Sousa et al., 2018) that evaluated the mortality of pearl mussels in the Rabaçal and Tuela basins during the summer of 2017 , in the current study we sampled both populations before and after the peak of the 2017 summer drought in order to assess possible differences in abundance and size structure. We hypothesize a significant reduction in abundance and change in the size structure of pearl mussels colonizing both basins due to the lower resistance (as a response to lower mobility and habitat preference) and resilience (due to long life cycle) of this species.

\section{Materials and methods}

Study area

Surveys were performed in the Rabaçal, Mente and Tuela Rivers, located in northern Portugal. Rabaçal, Mente and Tuela are tributaries of the Tua River (Douro basin) with lengths of 88, 57 and $102 \mathrm{~km}$, respectively (Fig. 1). The three rivers experience a similar climate, with a marked seasonal and interannual variation of temperature and precipitation (Oliveira et al., 2012; Sousa et al., 2015). This precipitation pattern is reflected in a variable river flow along the year, being higher during the winter and lower during the summer/early autumn months (Sousa et al., 2018). Part of the study area is included in a protected area, the Montesinho Natural Park. The three sampled rivers have a very low human pressure and are highly forested (mainly Quercus spp.) being considered an important habitat for threatened aquatic species such as pearl mussels $M$. margaritifera (Endangered), water desman Galemys pyrenaicus (Vulnerable) and Iberian loach Cobitis calderoni (Endangered) (Sousa et al., 2015, 2019). Despite the lower human disturbance, the three rivers have been threatened in the last decade by flow modification (dams and weirs), the introduction of non-native species (Sousa et al., 2019) and increasing occurrence of extreme climatic events such as floods and droughts (Sousa et al., 2012, 2018).

Sampling strategy and data analysis

Precipitation data since 1941 to 2018 were obtained from the European Climate Assessment \& Dataset project (http://www.ecad.eu) which comprises a daily dataset of surface air temperature and precipitation for the European countries (for details see Tank et al., 2002). Rainfall data were used as a proxy for river flow (Magalhães et al., 2007) since no data regarding this parameter exist for the three study rivers.

Margaritifera margaritifera surveys were carried out in late July/early August 2017 and again in the same period of 2018. In total, 30 sites were surveyed each year, being 15 sites located in Rabaçal River (R1-R15), 2 in Mente River (M1-M2) and 13 in Tuela River (T1-13) (Fig. 1). Individuals were surveyed by snorkelling in $50 \mathrm{~m}$ river stretches by three to four experienced divers (for the detailed methodology see Sousa et al., 2018). Four to nine search replicates (5 min per replicate) were accomplished for each site. The number of replicates was higher in sites with lower abundance. Abundance was expressed as the number of individuals per each 5 min search replicate (catch per unit of effort, CPUE). All mussels were measured with a Vernier calliper (to $0.1 \mathrm{~mm}$ ) and then returned to their habitat in the original position.

Differences in abundances of $M$. margaritifera between 2017 and 2018 and sites were assessed by a two-way ANOVA for the Rabaçal and Tuela basins separately. Since Mente River is a tributary of Rabaçal we joined the two sites of Mente River to the Rabaçal basin. Values for the abundances in the Rabaçal basin were log transformed in order to achieve a normal distribution. Differences in size of $M$. margaritifera between 2017 and 2018 were assessed by a $t$ test for the two basins. Size of pearl mussels found dead in 2017 was obtained through data already published in Sousa et al. (2018).

All the statistical analyses was performed with $\mathrm{R}$ Studio (Version 1.1.463).

\section{Results}

The 2017 drought in Portugal, and in the two river basins in particular, started in March and reached its 
Fig. 1 Map of the surveyed area in the Rabaçal (R), Mente (M) and Tuela (T) Rivers

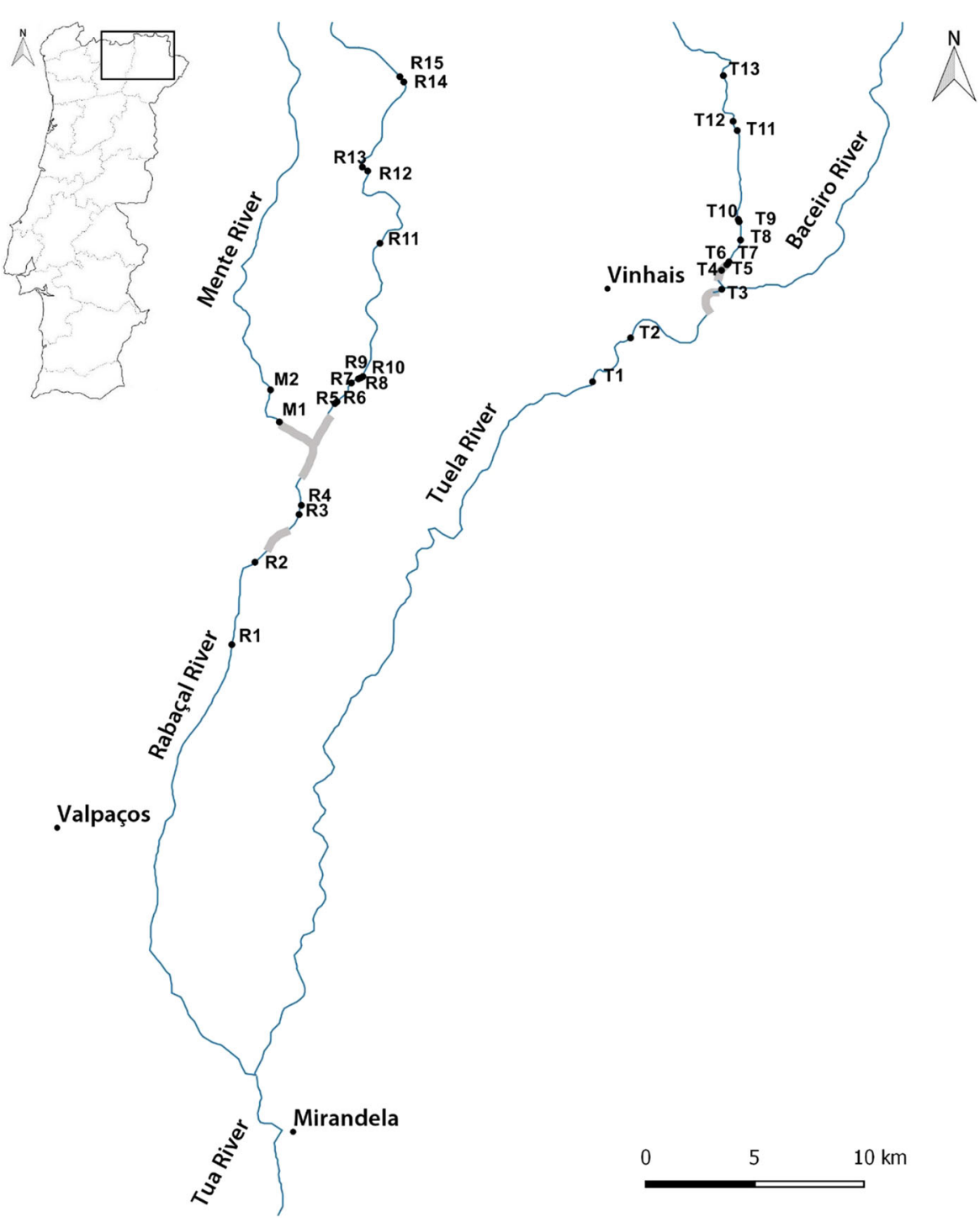

maximum severity from August to October. The cumulative precipitation recorded for the meteorological year of 2016/2017 (from October 2016 to September 2017) showed much lower values $(117.7 \mathrm{~mm})$ than the average registered since 1941 $(167.6 \mathrm{~mm})$, and those of the following year 2017/2018 (157.6 mm) (Fig. 2). Unfortunately, no data exist for the historical or current river flows in Rabaçal, Mente and Tuela Rivers. However, precipitation can be used as a good proxy for river flow and clearly from March 2017 to February 2018 we observed a great reduction in the precipitation when compared to historical data. This lack of precipitation was responsible for a rapid decrease in the river flow and water depth in the three surveyed rivers during summer. Although none of the rivers dried completely in any stretch, a considerable drop in water level was observed and shallower areas near the banks dried completely by the end of August (Fig. 3).

The average abundance in the Rabaçal basin was 25.2 ind.CPUE and 18.2 ind.CPUE in 2017 and 2018, respectively; corresponding to a decrease between years of $27.6 \%$. In the Tuela basin, the average of individuals surveyed was 9.4 ind.CPUE and 5.7 ind.CPUE in 2017 and 2018, respectively; corresponding to a decrease of $38.7 \%$. Abundance in the Rabaçal basin differed significantly between 2017 and 2018, $\left(P=0.0013 ; \quad F_{1}, \quad 133=10.75\right)$ and among sites 
Fig. 2 Cumulative precipitation $(\mathrm{mm})$ for the hydrological years (October to September) since 1941 up to 2018 (light grey), the year 2017 (black) and the year 2018 (dark grey)
1000

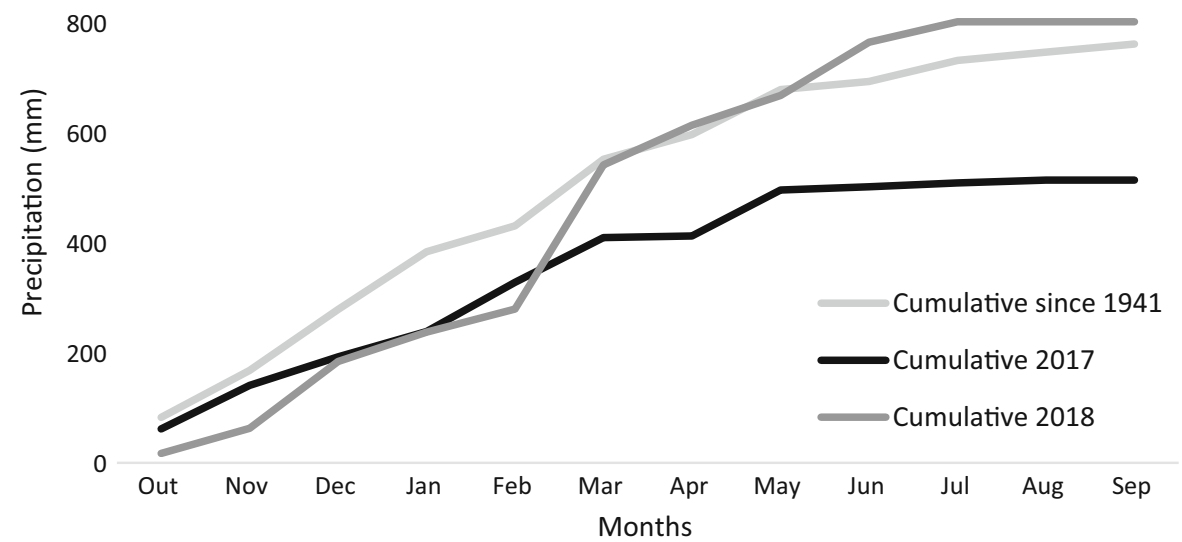

$\left(P<0.0001 ; F_{16}, 133=54.66\right)$, with a significant interaction between years and sites $(P<0.0001$; $F_{16,133}=3.363$ ) (Fig. 4a). The same happens in the Tuela basin, where abundance was significantly lower in 2018 compared to $2017 \quad(P<0.0001$; $\left.F_{1,140}=22.61\right)$. A significant difference was also found among sites $\left(P<0.0001 ; F_{12,140}=35.45\right)$, with a significant interaction between years and sites $\left(P=0.0185 ; F_{12,140}=2.130\right)($ Fig. $4 b)$.

Significant differences were found in the average size between 2017 and 2018 in Rabaçal basin and this is probably related to the large sample size $(t=3.65$,
$P<0.001$ ) (Fig. 5a). However, no differences were detected in the Tuela basin $(t=-1.47, P=0.1414)$ (Fig. 5b). Average sizes were smaller at sites with higher average abundance (Pearson's $r=-0.49$; $P<0.001)$ given the higher percentage of juveniles in sites with higher abundances (data not shown). Percentage of individuals by size categories remained relatively similar after the drought and follow also similar results reported by Sousa et al. (2018) for the mussels found dead near the banks, being the higher percentage of individuals found in the 60-70 and 70-80 mm size categories (Fig. 6).

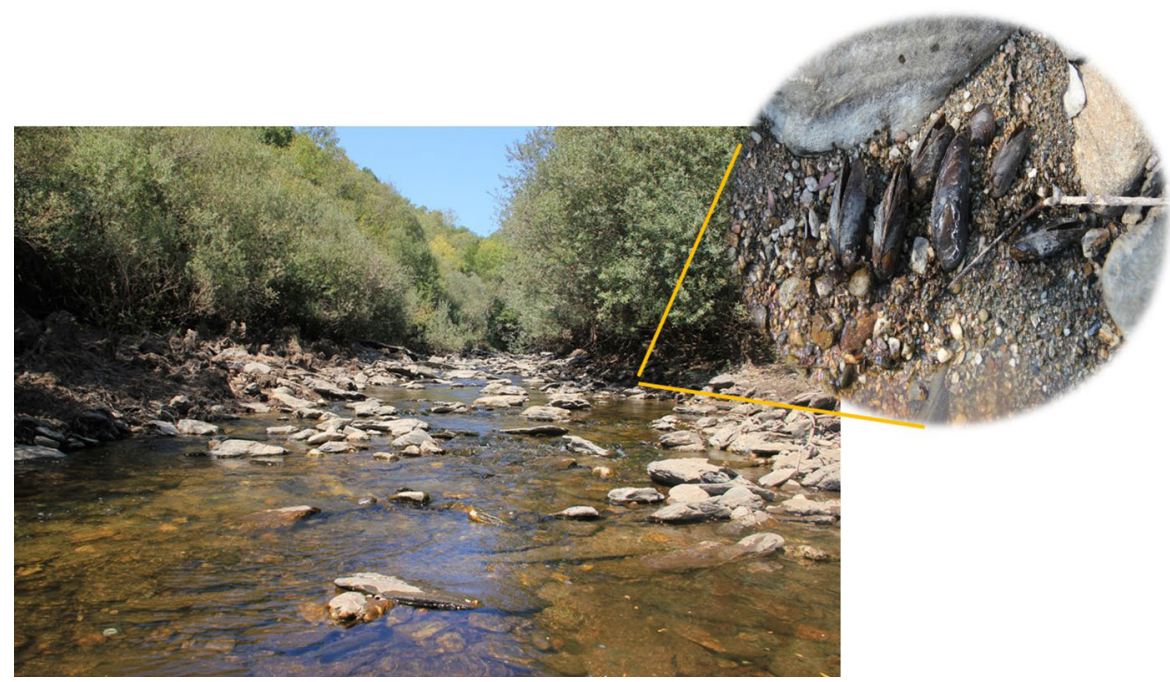

Fig. 3 Rabaçal River in August 2017 showing the very low flow and desiccation on the banks of Margaritifera margaritifera individuals 
Fig. 4 Boxplots showing the abundances (ind. CPUE) for the species

Margaritifera margaritifera in the Rabaçal basin (a) and the Tuela basin (b) between the years 2017 and 2018 .

Boxplots show median values (central line), the range from the 25 th to 75 th percentile (box) and the largest and lowest value within 1.5 times interquartile range below and above the 25th and 75th percentile (whiskers) and dots represent extreme values
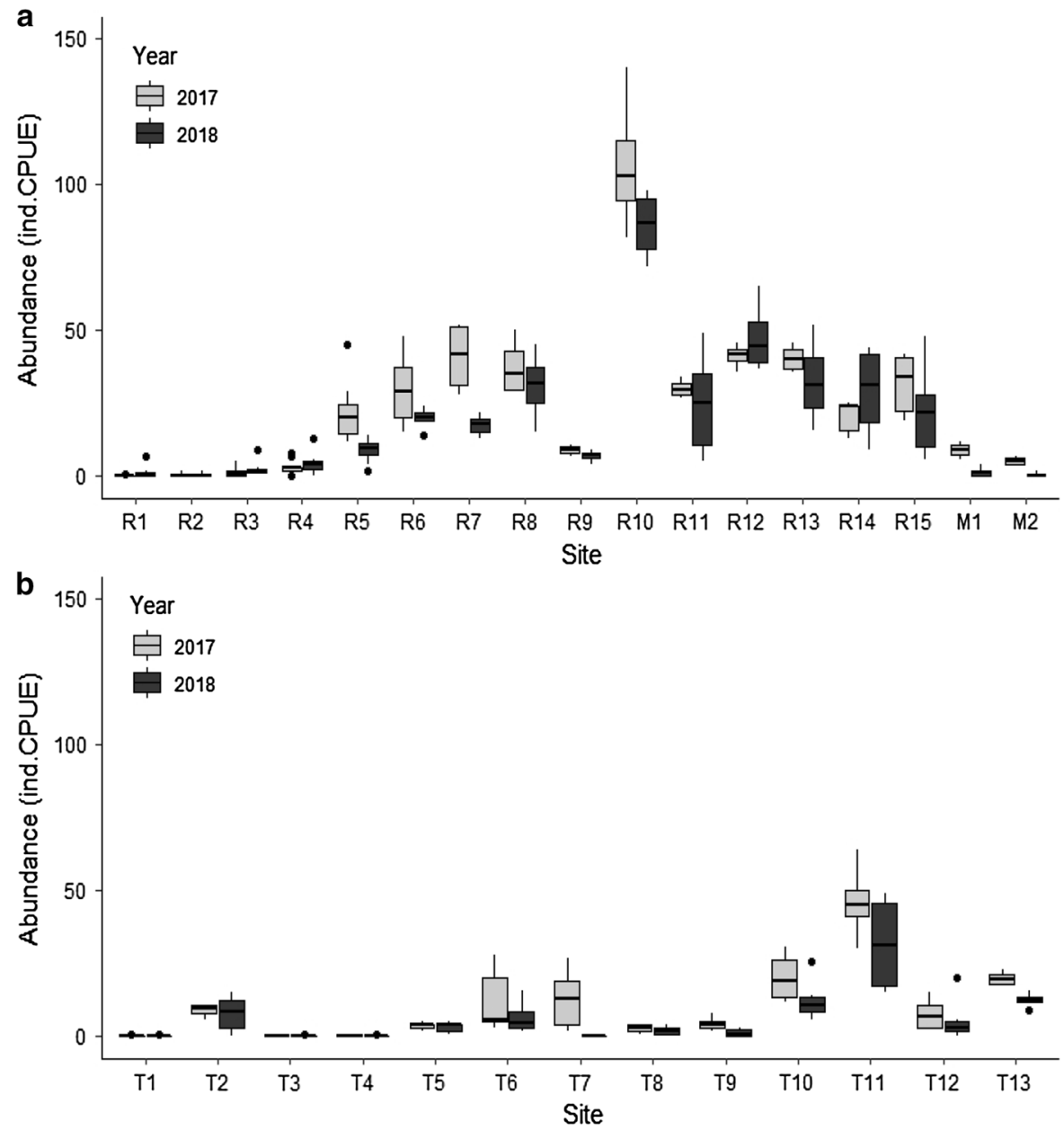

\section{Discussion}

In 2017 Portugal was subjected to very low precipitation, and the Palmer Drought Severity Index showed that by October $24.8 \%$ of the territory was already suffering a severe drought being the remaining $75.2 \%$ under an extreme drought (IPMA, 2019). This extreme climatic event led to the decrease of river flow causing the mortality of $M$. margaritifera individuals in the Rabaçal and Tuela basins (for details on these mortalities see Sousa et al., 2018). In this study we clearly show that the extreme 2017 summer drought affected the abundance of the pearl mussel $M$. margaritifera in the southern edge of its distribution and this situation may impair the future conservation of this species.

As expected, and given the large spatial scale and the number of sites surveyed in this study, spatial heterogeneity is responsible for different abundances across sites and this situation was already described for the Rabaçal and Tuela basins in earlier studies (Sousa et al., 2015). Despite being out of the scope of this study (i.e. assessment of microhabitat preferences), M. margaritifera has certain habitat preferences such as: a river bed composed by boulders, gravel and sand with very low organic matter content, shallow areas with a depth up to $0.8 \mathrm{~m}$ and a current velocity up to $0.2 \mathrm{~ms}^{-1}$ in Portuguese rivers during summer conditions (Varandas et al., 2013). Therefore, it is expected that sites subjected to these ideal conditions (for example sites R10 and T11) have higher abundances than those sites that depart from these characteristics (for example sites R1, R2, R3, T1, $\mathrm{T} 3$ and T4).

The reduction in water flow and sudden decrease in the water levels led to mussels stranding in the river 

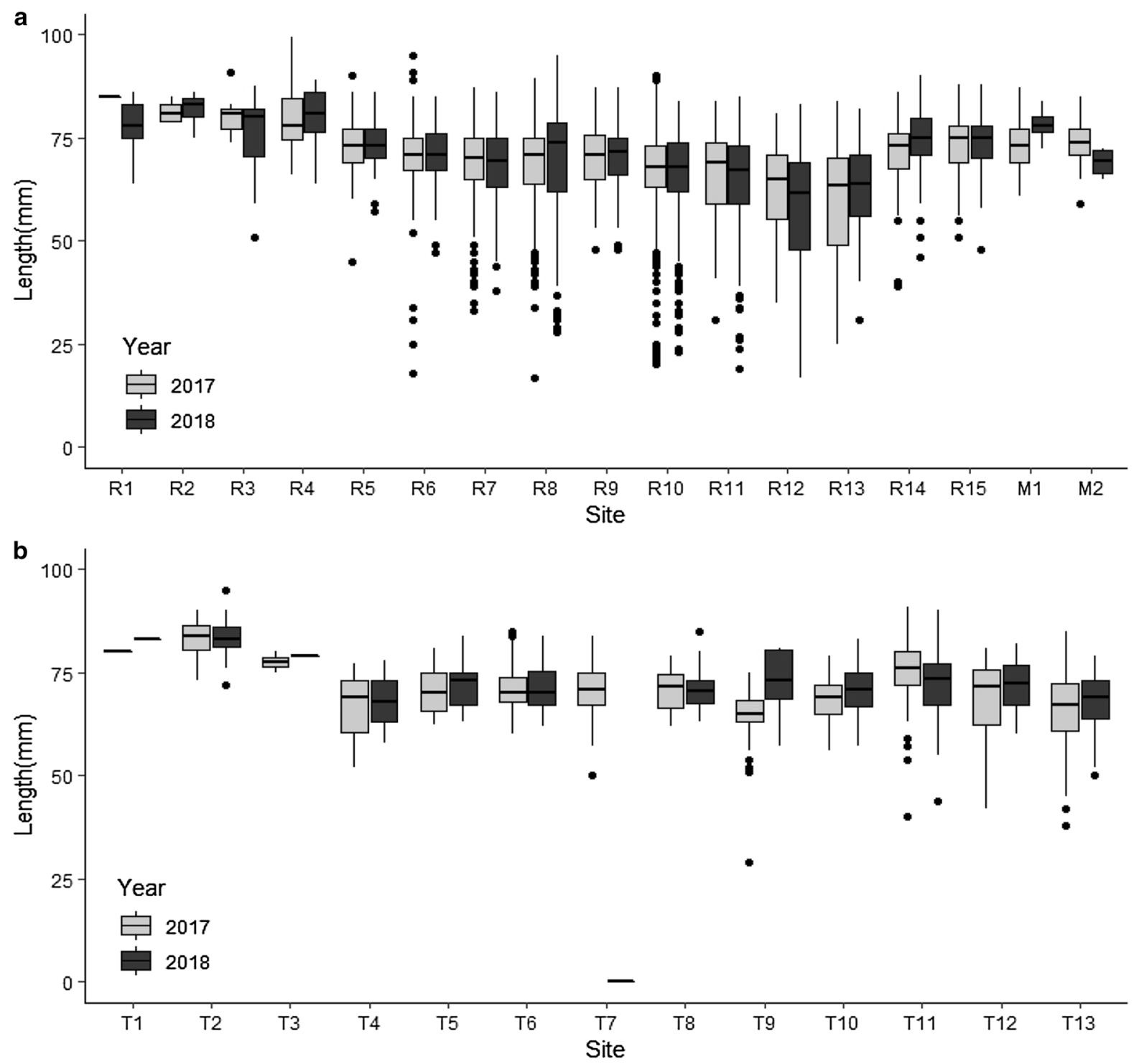

Fig. 5 Boxplots showing the sizes (mm) for the species Margaritifera margaritifera in the Rabaçal basin (a) and the Tuela basin (b) between the years 2017 and 2018. Boxplots show median values (central line), the range from the 25 th to

banks and to an increase in predation by wild boar Sus scrofa. These two mechanisms were responsible for the massive mortalities reported in Sousa et al. (2018). Pearl mussels have no mobility and prefer habitats near the banks (Sousa et al., 2015), enhancing the vulnerability of this species to supra-seasonal droughts. According to Morales \& Lizana (2014) similar results were reported for the Negro River (Douro basin, Spain) during the 2009 summer drought, with a recorded mortality of $37 \%$. In addition, 75th percentile (box) and the largest and lowest value within 1.5 times interquartile range below and above the 25th and 75th percentile (whiskers) and dots represent extreme values

increased predation by wild boars was also detected in the Negro River (Morales et al., 2011). In larger streams, sites with permanent pools are more difficult to dry, decreasing the risk of mortality associated with desiccation and predation (Gagnon et al., 2004). On the contrary, sites located in shallow areas, with riffles, are more likely to increase the species vulnerability to emersion due to the lack of deeper refuges, resulting in higher mortality rates. For instance, the differences in abundance were higher in the site R5 (Rabaçal River), 
Fig. 6 Percentage of Margaritifera margaritifera individuals in each size category in 2017 (light grey) and 2018 (dark grey), and found dead in 2017 (black) (data from Sousa et al., 2018) in Rabaçal basin (a) and the Tuela basin (b)

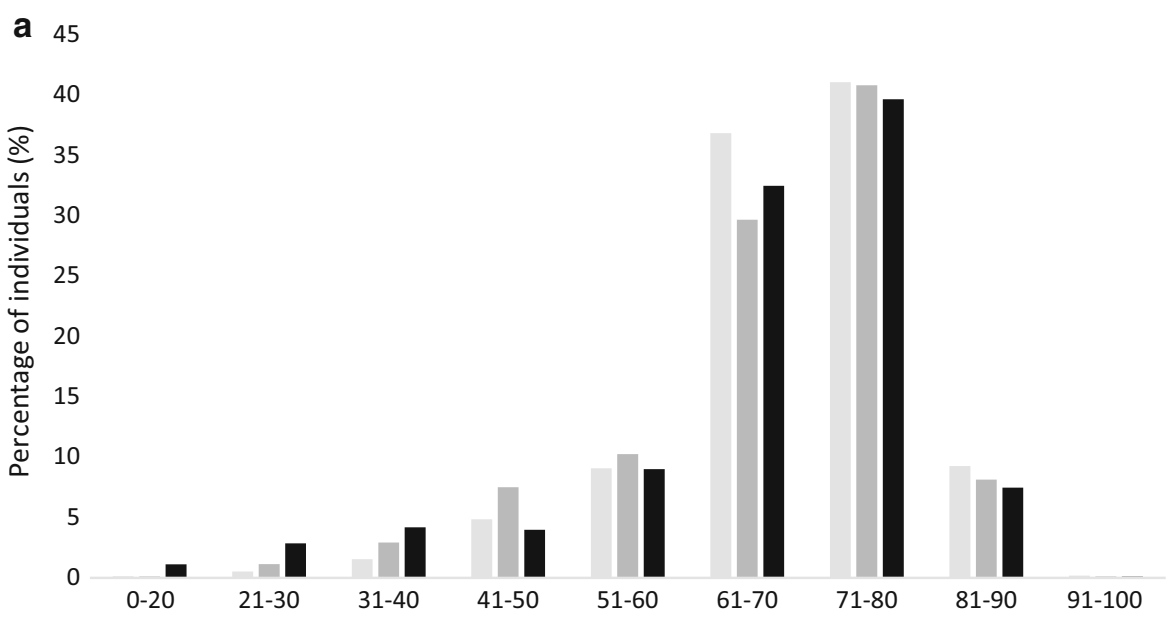

b 60

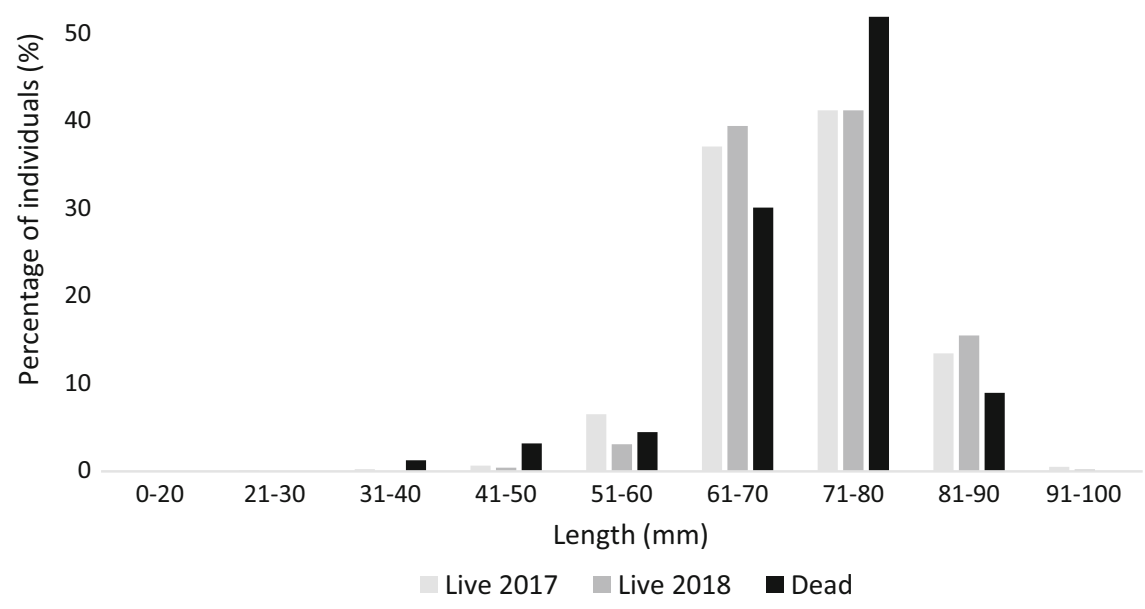

in both sites of the Mente River, as well as in T7 and T11 (Tuela River), being all these sites very shallow and located in riffles. On the other hand, differences in abundance between 2017 and 2018 were smaller in sites located in deeper areas, such as R12 (Rabaçal River) and T2 (Tuela River).

According to other studies (e.g. Gagnon et al., 2004), oxygen levels may decrease during drought conditions and be responsible for high mortalities in freshwater mussels. However, this was not the case in this study since oxygen levels were high, only varying between 7 and $9 \mathrm{mg} \mathrm{l}^{-1}$ during the summer of 2017 (authors personal observation).

Given the decrease in abundance in both basins after the drought, it is clear that this species has low resistance to these extreme climatic events, being this situation mainly caused by the low mobility of these organisms. In addition, we cannot exclude that pearl mussels that were not killed by desiccation, but were in a situation of inadequate flow velocity for a prolonged period, suffered from a reduction in muscular condition being more vulnerable to death during the next period of high flow, when they can be washed onto the river bank or downstream into inappropriate habitat. However, as this situation was not assessed in this study, its importance remains speculative and should be further investigated. In fact, extreme droughts are not the only climatic threat to this species, as floods may also be responsible for high mortalities (Sousa et al., 2012). For example, a major flood in 1998 on the Kerry River (Scotland), one of the largest pearl mussel populations in the world, caused a 
M. margaritifera population decline of $4-8 \%$ (estimated mortality of 50,000 individuals) (Hastie et al., 2001).

The effects of the 2017 drought in the pearl mussel populations were felt in all size categories, and so the size structure was maintained reasonably stable after the drought. The percentage of individuals found dead in 2017 (data collected by Sousa et al., 2018) in each size category is similar to the observed before/after the drought, as most pearl mussels belong to the $60-70$ and $70-80 \mathrm{~mm}$ categories. Therefore, in this study we were not able to observe a higher vulnerability of juveniles (or any size category) to drought conditions.

The freshwater pearl mussel populations in Portugal suffered a severe decline in the last decades being the Rabaçal and Tuela basins considered as the most important populations in the country (Sousa et al., 2015). The declines in abundance reported here (i.e. $27.6 \%$ and $38.7 \%$ for Rabaçal and Tuela basins, respectively) are alarming and turn urgent the conservation of both populations. Anyway, results should be interpreted with some cautions as other factors like the sampling conditions in both years (e.g. visibility or current velocity) may introduce some bias. However, this bias should be minimal since surveys were performed by the same divers, sampling sites and number of replicates were the same, and visibility conditions during surveys were excellent.

As climate change interacts synergistically with other stressors (e.g. habitat degradation and fragmentation, and introduction of non-native species), it is crucial to assess the consequences of future droughts on both populations and provide management solutions that may mitigate impacts. Extreme droughts are projected to increase in number and intensity (Easterling et al., 2000), and so it is necessary to monitor populations of $M$. margaritifera, as this species may not adapt to extreme conditions. The decrease in pearl mussel abundance may also implicate the loss of important ecosystem functions such as sediment mixing, water filtering, nutrient release and their shells provide habitat for other species (Geist, 2010; Vaughn \& Hakenkamp, 2001). In addition, and beyond direct mortality as reported here, extreme thermal conditions can potentially affect the reproduction of pearl mussels (Hastie et al., 2003), as they release glochidia in late summer (August-September) when the river flow is the lowest in the study area.
Given the complex life cycle, low dispersal capacity, the restricted ecological niche and the existence of other environmental stressors (invasive species; Sousa et al., 2019), this species, in addition to the apparent low resistance to climatic extremes, also seems to have very low resilience. This means that both populations could take years to recover or not recover at all. One way to assess the species future resilience is by careful monitoring of these populations, including on critical periods of low river flow. During future drought conditions, and if necessary, pearl mussels from the most affected areas should be transferred to deeper areas and/or to laboratory until better environmental conditions return and turn possible the transfer of organisms to their original sites. In alternative, reproduction in captivity and posterior release into the wild accompanied by genetic studies, monitoring of the fish host (the brown trout Salmo trutta) and by stream restoration, are also possible management actions to be taken in order to increase $M$. margaritifera resilience. Although reproduction in captivity can be constrained by the complexity of the life cycle of pearl mussels, there has been successful cases in Germany, Northern Ireland and many other European countries (review in Gum et al., 2011). In addition, and even though most individuals are located upstream the influence of small dams, sites located downstream could potentially benefit from a better management of river flow, especially during the dry season. Also, it would be pertinent to forecast future climatic scenarios for M. margaritifera distribution at different spatial scales (following Santos et al., 2015; Bolotov et al., 2018).

In conclusion, this study shows how an extreme climatic event directly affected the abundance of two of the most important Iberian pearl mussel populations. Although being a conservation target in Europe, this species is decreasing in distribution and abundance, and future management should include in-situ and ex-situ actions, as well as long-term monitoring. The degree of impact of climate change on pearl mussel populations also depends on other human activities, as water abstraction (for agriculture) and bad management of river flow (due to dam operations) exacerbate the problem. Given the decline in abundance reported here, it is crucial to include the assessment of impacts of extreme climatic events on conservation planning and management of $M$. margaritifera. 
Acknowledgements This work was supported by: (i) POSEUR-03-2215-FC-000096 and ICNF funds under Project CP01-MARG-QUERCUS/2018 and (ii) European Investment Funds by FEDER/COMPETE/POCI - Operational Competitiveness and Internationalization Program, under Project POCI-01-0145-FEDER-006958 and National Funds by FCT - Portuguese Foundation for Science and Technology, under the project UID/AGR/04033/2013. FCT also support MLL with a doctoral Grant (SFRH/BD/115728/2016). We are grateful to José Pedro Ramião for the help with the precipitation data.

\section{References}

Bellard, C., C. Bertelsmeier, P. Leadley, W. Thuiller \& F. Courchamp, 2012. Impacts of climate change on the future of biodiversity. Ecology Letters 15: 365-377.

Bolotov, I. N., A. A. Makhrov, M. Y. Gofarov, O. V. Aksenova, P. E. Aspholm, Y. V. Bespalaya, M. B. Kabakov, Y. S. Kolosova, A. V. Kondakov, T. Ofenböck, A. N. Ostrovsky, I Yu Popov, T. von Proschwitz, M. Rudzīte, M. Rudzītis, S. E. Sokolova, I. Valovirta, I. V. Vikhrev, M. V. Vinarski \& A. A. Zotin, 2018. Climate warming as a possible trigger of keystone mussel population decline in oligotrophic rivers at the continental scale. Scientific Reports 8: 1-9.

Bond, N. R., P. S. Lake \& A. H. Arthington, 2008. The impacts of drought on freshwater ecosystems: an Australian perspective. Hydrobiologia 600: 3-16.

Chester, E. T. \& B. J. Robson, 2011. Drought refuges, spatial scale and recolonization by invertebrates in non-perennial streams. Freshwater Biology 56: 2094-2104.

Easterling, D. R., G. A. Meehl, C. Parmesan, S. A. Changnon, T. R. Karl \& L. O. Mearns, 2000. Climate extremes: observations, modeling, and impacts. Science 289: 2068-2074.

Gagnon, P. M., S. W. Golladay, W. K. Michener \& M. C. Freeman, 2004. Drought responses of freshwater mussels (unionidae) in coastal plain tributaries of the Flint River basin, Georgia. Journal of Freshwater Ecology 19: 667-679.

Galbraith, H. S., D. E. Spooner \& C. C. Vaughn, 2010. Synergistic effects of regional climate patterns and local water management on freshwater mussel communities. Biological Conservation 143: 1175-1183.

Garrabou, J., R. Coma, N. Bensoussan, M. Bally, P. Chevaldonné, M. Cigliano, D. Diaz, J. G. Hamerlin, M. C. Gambi, D. K. Kersting, J. B. Ledoux, C. Lejeusne, C. Linares, C. Marschal, T. Pérez, M. Ribes, J. C. Romano, E. Serrano, N. Teixido, O. Torrents, M. Zabala, F. Zuberer \& C. Cerrano, 2009. Mass mortality in Northwestern Mediterranean rocky benthic communities: effects of the 2003 heat wave. Global Change Biology 15: 1090-1103.

Geist, J., 2010. Strategies for the conservation of endangered freshwater pearl mussels (Margaritifera margaritifera $\mathrm{L}$.): a synthesis of conservation genetics and ecology. Hydrobiologia 644: 69-88.

Golladay, S. W., P. Gagnon, M. Kearns, J. M. Battle \& D. W. Hicks, 2004. Response of freshwater mussel assemblages (Bivalvia: Unionidae) to a record drought in the
Gulf Coastal Plain of southwestern Georgia. Journal of the North American Benthological Society 23: 494-506.

Gum, B., M. Lange \& J. Geist, 2011. A critical reflection on the success of rearing and culturing juvenile freshwater mussels with a focus on the endangered freshwater pearl mussel (Margaritifera margaritifera L.). Aquatic Conservation: Marine and Freshwater Ecosystems 21: 743-751.

Haag, W. R. \& M. L. Warren, 2008. Effects of severe drought on freshwater mussel assemblages. Transactions of the American Fisheries Society 137: 1165-1178.

Harris, R. M., L. J. Beaumont, T. R. Vance, C. R. Tozer, T. A. Remenyi, S. E. Perkins-Kirkpatrick, P. J. Mitchell, A. B. Nicotra, S. McGregor, N. R. Andrew, M. Letnic, M. R. Kearney, T. Wernberg, L. B. Hutley, L. E. Chambers, M.-S. Fletcher, M. R. Keatley, C. A. Woodward, C. Williamson, N. S. Duke \& D. M. J. S. Bowman, 2018. Biological responses to the press and pulse of climate trends and extreme events. Nature Climate Change 8: 579-587.

Hastie, L. C., P. J. Boon, M. R. Young \& S. Way, 2001. The effects of a major flood on an endangered freshwater mussel population. Biological Conservation 98: 107-115.

Hastie, L. C., P. J. Cosgrove, N. Ellis \& M. J. Gaywood, 2003. The threat of climate change to freshwater pearl mussel populations. AMBIO: A Journal of the Human Environment 32: 40-47.

Humphries, P. \& D. S. Baldwin, 2003. Drought and aquatic ecosystems: an introduction. Freshwater Biology 48: 1141-1146.

IPMA, 2019. http://www.ipma.pt. Accessed Jan 31.

Lake, P. S., 2003. Ecological effects of perturbation by drought in flowing waters. Freshwater Biology 48: 1161-1172.

Lake, P. S., 2011. Drought and Aquatic Ecosystems. Effects and Responses, 1st ed. Wiley-Blackwell, Oxford, UK.

Lopes-Lima, M., A. Teixeira, E. Froufe, A. Lopes, S. Varandas \& R. Sousa, 2014. Biology and conservation of freshwater bivalves: past, present and future perspectives. Hydrobiologia 735: 1-13.

Lopes-Lima, M., R. Sousa, J. Geist, D. C. Aldridge, R. Araujo, J. Bergengren, Y. Bespalaya, E. Bódis, L. Burlakova, D. Van Damme, K. Douda, E. Froufe, D. Georgiev, C. Gumpinger, A. Karatayev, U. Kebapçi, I. Killeen, J. Lajtner, B. M. Larsen, R. Lauceri, A. Legakis, S. Lois, S. Lundberg, E. Moorkens, G. Motte, K.-O. Nagel, P. Ondina, A. Outeiro, M. Paunovic, V. Prié, T. von Proschwitz, N. Riccardi, M. Rudzīte, M. Rudzītis, C. Scheder, M. Seddon, H. Şereflişan, V. Simic, S. Sokolova, K. Stoeckl, J. Taskinen, A. Teixeira, F. Thielen, T. Trichkova, S. Varandas, H. Vicentini, K. Zajac, T. Zajac \& S. Zogaris, 2017. Conservation status of freshwater mussels in Europe: state of the art and future challenges. Biological Reviews 92: 572-607.

Lopes-Lima, M., L. E. Burlakova, A. Y. Karatayev, K. Mehler, M. Seddon \& R. Sousa, 2018. Conservation of freshwater bivalves at the global scale: diversity, threats and research needs. Hydrobiologia 810: 1-14.

Magalhães, M. F., P. Beja, I. J. Schlosser \& M. J. CollaresPereira, 2007. Effects of multi-year droughts on fish assemblages of seasonally drying Mediterranean streams. Freshwater Biology 52: 1494-1510.

Maxwell, S. L., N. Butt, M. Maron, C. A. McAlpine, S. Chapman, A. Ullmann, D. B. Segan \& J. E. Watson, 2019. Conservation implications of ecological responses to 
extreme weather and climate events. Diversity and Distributions 25: 613-625.

Morales, J. \& M. Lizana, 2014. Efectos negativos del cambio climático aceleran la extinción de la principal población de la náyade Margaritifera margaritifera L., 1758 en la cuenca del Duero. Munibe Ciências Naturales 62: $103-127$.

Morales, J., E. Peñín \& M. Lizana, 2011. Depredación ocasional de Sus scrofa L. sobre una metapoblación relíctica de Margaritifera margaritifera L. (Bivalvia: Mollusca) en el río Negro (NO de España). Galemys 23: 51-56.

Oliveira, J. M., P. Segurado, J. M. Santos, A. Teixeira, M. T. Ferreira \& R. V. Cortes, 2012. Modelling stream-fish functional traits in reference conditions: regional and local environmental correlates. PLoS ONE 7: e45787.

Rammig, A. \& M. D. Mahecha, 2015. Ecosystem responses to climatic extremes. Nature 527: 315-316.

Sales, K., R. Vasudeva, M. E. Dickinson, J. L. Godwin, A. J. Lumley, L. Michalczyk, L. Hebberecht, P. Thomas, A. Franco \& M. J. G. Gage, 2018. Experimental heatwaves compromise sperm function and cause transgenerational damage in a model insect. Nature Communications 9: 477.

Santos, R. M. B., L. F. Sanches Fernandes, S. G. P. Varandas, M. G. Pereira, R. Sousa, A. Teixeira, M. Lopes-Lima, R. M. V. Cortes \& F. A. L. Pacheco, 2015. Impacts of climate change and land-use scenarios on Margaritifera margaritifera, an environmental indicator and endangered species. Science of the Total Environment 511: 477-488.

Siegmund, J. F., M. Wiedermann, J. F. Donges \& R. V. Donner, 2016. Impact of temperature and precipitation extremes on the flowering dates of four German wildlife shrub species. Biogeosciences 13: 5541-5555.

Sousa, R., S. Varandas, R. Cortes, A. Teixeira, M. Lopes-Lima, J. Machado \& L. Guilhermino, 2012. Massive die-offs of freshwater bivalves as resource pulses. Annales Limnologie-International Journal of Limnology 48: 105-112.

Sousa, R., Â. Amorim, C. Sobral, E. Froufe, S. Varandas, A. Teixeira \& M. Lopes-Lima, 2013. Ecological status of a Margaritifera margaritifera (Linnaeus, 1758) population at the southern edge of its distribution (River Paiva, Portugal). Environmental Management 52: 1230-1238.

Sousa, R., Â. Amorim, E. Froufe, S. Varandas, A. Teixeira \& M. Lopes-Lima, 2015. Conservation status of the freshwater pearl mussel Margaritifera margaritifera in Portugal. Limnologica 50: 4-10.

Sousa, R., A. Ferreira, F. Carvalho, M. Lopes-Lima, S. Varandas \& A. Teixeira, 2018. Die-offs of the endangered pearl mussel Margaritifera margaritifera during an extreme drought. Aquatic Conservation: Marine and Freshwater Ecosystems 28: 1244-1248.

Sousa, R., J. G. Nogueira, A. Ferreira, F. Carvalho, M. LopesLima, S. Varandas \& A. Teixeira, 2019. A tale of shells and claws: the signal crayfish as a threat to the pearl mussel Margaritifera margaritifera in Europe. Science of the Total Environment 665: 329-337.

Sterl, A., C. Severijns, H. Dijkstra, W. Hazeleger, G. J. van Oldenborgh, M. van den Broeke, G. Burgers, B. van den Hurk, P. J. van Leeuwen \& P. van Velthoven, 2008. When can we expect extremely high surface temperatures? Geophysical Research Letters 35: 1-5.

Tank, A. M. G. K., J. B. Wijngaard, G. P. Können, R. Böhm, G. Demarée, A. Gocheva, M. Mileta, S. Pashiardis, L. Hejkrlik, C. Kern-Hansen, R. Heino, P. Bessermoulin, G. Muller-Westermeier, M. Tzanakou, S. Szalai, T. Pálsdóttir, D. Fitzgerald, S. Rubin, M. Capaldo, M. Maugeri, A. Leitass, A. Bukantis, R. Aberfeld, A. F. V. van Engelen, E. Forland, M. Mietus, F. Coelho, C. Mares, V. Razuvaev, E. Nieplova, T. Cegnar, J. António López, B. Dahlstrom, A. Moberg, W. Kirchhofer, A. Ceylan, O. Pachaliuk, L. V. Alexander \& P. Petrovic, 2002. Daily dataset of 20thcentury surface air temperature and precipitation series for the European Climate Assessment. International Journal of Climatology 22: 1441-1453.

Varandas, S., M. Lopes-Lima, A. Teixeira, M. Hinzmann, J. Reis, R. Cortes, J. Machado \& R. Sousa, 2013. Ecology of southern European pearl mussels (Margaritifera margaritifera): first record of two new populations on the rivers Terva and Beça (Portugal). Aquatic Conservation: Marine and Freshwater Ecosystems 23: 374-389.

Vaughn, C. C. \& C. C. Hakenkamp, 2001. The functional role of burrowing bivalves in freshwater ecosystems. Freshwater Biology 46: 1431-1446.

Walther, G. R., E. Post, P. Convey, A. Menzel, C. Parmesan, T. J. Beebee, J.-M. Fromentin, O. Hoegh-Guldberg \& F. Bairlein, 2002. Ecological responses to recent climate change. Nature 416: 389-395.

Winemiller, K. O. \& J. B. Jepsen, 1998. Effects of seasonality and fish movement on tropical river food webs. Journal of Fish Biology 53: 267-296.

Wuethrich, B., 2000. How climate change alters rhythms of the wild. Science 287: 793-795.

Publisher's Note Springer Nature remains neutral with regard to jurisdictional claims in published maps and institutional affiliations. 